\title{
Article \\ Evidence of the Physical Interaction between Rp122 and the Transposable Element Doc5, a Heterochromatic Transposon of Drosophila melanogaster
}

\author{
Maria Francesca Berloco ${ }^{1,+}$, Crescenzio Francesco Minervini ${ }^{2,+}{ }^{+}$, Roberta Moschetti ${ }^{1}$, Antonio Palazzo ${ }^{1}(\mathbb{D}$, \\ Luigi Viggiano $1, *, \ddagger$ and René Massimiliano Marsano $1, *, \ddagger, \S(\mathbb{D}$ \\ 1 Department of Biology, University of Bari "Aldo Moro", 70126 Bari, Italy; \\ mariafrancesca.berloco@uniba.it (M.F.B.); roberta.moschetti@uniba.it (R.M.); antonio.palazzo@uniba.it (A.P.) \\ 2 Department of Emergency and Organ Transplantation (D.E.T.O.), Hematology and Stem Cell Transplantation \\ Unit, University of Bari “Aldo Moro", 70124 Bari, Italy; crescenziofrancesco.minervini@uniba.it \\ * Correspondence: luigi.viggiano@uniba.it (L.V.); renemassimiliano.marsano@uniba.it (R.M.M.) \\ + joint first authors. \\ $\ddagger$ joint corresponding authors. \\ $\S$ Former affiliation: Department of Genetics Anthropology Evolution, University of Parma, Parco Area delle \\ Scienze 11/A, 43124 Parma, Italy.
}

check for updates

Citation: Berloco, M.F.; Minervini, C.F.; Moschetti, R.; Palazzo, A.; Viggiano, L.; Marsano, R.M. Evidence of the Physical Interaction between Rpl22 and the Transposable Element Doc5, a Heterochromatic Transposon of Drosophila melanogaster. Genes 2021, 12, 1997. https://doi.org/ 10.3390/genes12121997

Academic Editor: Miroslav Plohl

Received: 6 November 2021

Accepted: 12 December 2021

Published: 16 December 2021

Publisher's Note: MDPI stays neutral with regard to jurisdictional claims in published maps and institutional affiliations.

Copyright: (c) 2021 by the authors. Licensee MDPI, Basel, Switzerland. This article is an open access article distributed under the terms and conditions of the Creative Commons Attribution (CC BY) license (https:// creativecommons.org/licenses/by/ $4.0 /)$.
Abstract: Chromatin is a highly dynamic biological entity that allows for both the control of gene expression and the stabilization of chromosomal domains. Given the high degree of plasticity observed in model and non-model organisms, it is not surprising that new chromatin components are frequently described. In this work, we tested the hypothesis that the remnants of the Doc5 transposable element, which retains a heterochromatin insertion pattern in the melanogaster species complex, can be bound by chromatin proteins, and thus be involved in the organization of heterochromatic domains. Using the Yeast One Hybrid approach, we found Rpl22 as a potential interacting protein of Doc5. We further tested in vitro the observed interaction through Electrophoretic Mobility Shift Assay, uncovering that the $\mathrm{N}$-terminal portion of the protein is sufficient to interact with Doc5. However, in situ localization of the native protein failed to detect Rpl22 association with chromatin. The results obtained are discussed in the light of the current knowledge on the extra-ribosomal role of ribosomal protein in eukaryotes, which suggests a possible role of Rpl22 in the determination of the heterochromatin in Drosophila.

Keywords: ribosomal protein; Rpl22; Drosophila; DNA-protein interaction; transposable elements; heterochromatin; Doc5/Porto1

\section{Introduction}

Chromatin [1] is a nucleoprotein complex that plays a key role in controlling cell behavior and chromosomal structure [2,3]. Its regulation is important in the control of cellular events, including genome packaging, replication, recombination, DNA repair, and transcription. The nucleosome, which comprises the four core histones $(\mathrm{H} 2 \mathrm{~A}, \mathrm{H} 2 \mathrm{~B}, \mathrm{H} 3$, $\mathrm{H} 4$ ), wrapped around with $168 \mathrm{bp}$ of DNA, and the linker histones H1 or H5 form the chromatosome, the structural unit of the chromatin [4].

Chromatin is found in two fundamental states during the cell cycle, the loosely condensed euchromatin and the highly compacted heterochromatin. A huge number of DNA-protein and protein-protein interactions contribute to the maintenance of these two structures, the plasticity of which is tightly regulated at the epigenetic level.

Many proteins act as structural components or regulators of the chromatin state, and post-translational modifications of many chromatin components play a fundamental role in maintaining the dynamic state of different chromatin domains. The ongoing EN- 
CODE projects $[5,6]$ aim to determine the nature of the epigenetic code and to what extent chromatin remodeling could influence the phenotypes.

Several pieces of observation suggest that ribosomal proteins (RPs) could have an active role in chromatin dynamics. First, RNA-mediated processes have a functional role in regulating chromatin structure and gene expression through the action of non-coding RNA molecules [7-9]. Second, a large fraction of the expressed lncRNA interacts with ribosomes in humans and mice (roughly $39 \%$ and $48 \%$, respectively) [10].

Third, the presence of RPs in the nucleus is well-recognized since RPs are imported into the nucleus and assembled into pre-ribosomes in the nucleolus [11].

Therefore, a subset of RPs could be co-opted as chromatin components to perform additional functions under either physiological or exceptional conditions.

Heterochromatin is a partition of the eukaryotic genome, often regarded as useless and functionless. This concept is due to its low gene density and the consequent low impact of mutational load in this compartment on viability and fertility. The massive presence of satellite DNA and transposons in the constitutive heterochromatin has further reinforced this idea. However, since heterochromatin is associated with important functions and structures of the eukaryotic chromosomes, its role has been recently re-evaluated, both in model and non-model organisms. In D. melanogaster, several hundreds of genes have been mapped in the constitutive heterochromatin, thus demonstrating its importance in the physiology of cells, tissues, and organs in the fly [12], an observation largely supported by classic and modern genetics studies.

Several additional features make heterochromatin a fascinating genomic compartment. These include the massive presence of repeats and transposable elements, whose structural and functional roles remain elusive, despite decades of studies. In this respect, noteworthy examples still come from $D$. melanogaster. Several repeated loci have been characterized so far in the heterochromatin of D. melanogaster, and some of them play an extremely important role in determining critical phenotypes [13-15]. One of these relevant loci lies in the h39 region, a Hoechst-bright chromosomal band adjacent to the centromere of the second chromosome. Two well-studied satellite DNA sequences are clustered in the h39 region, the Responder locus (Rsp), and the Bari1 repeat. The Rsp locus, in combination with the $S d$ euchromatic locus, constitutes the key components of one of the best-known segregation distortion systems [13]. The Bari1 cluster is an array of roughly 80 copies of the Bari1 transposon [16-18], depending on the fly strain [18,19] of the Bari1 transposon. Elements of the Bari1 family are Tc1-like transposons that have colonized the genome of several Drosophila species [17] and are active in the respective genomes [20,21].

The characterization of the Bari1 copy number variation in several $D$. melanogaster populations $[16,18,19]$ revealed that this is an extremely static array if compared to the closely linked Rsp locus [22,23]. Considering that the Bari1 cluster origin probably dates back to the split of the melanogaster and simulans species, approximately $5 \mathrm{Mya}$, and that it is only present in D. melanogaster $[16,17,24]$, it has been speculated that either it could be functionally connected to the Rsp locus or to other structural features of the h39 region. However, the presence of a small Bari1 cluster on the $\mathrm{X}$ chromosome $[17,25]$ and an additional small Rsp repeat on the third chromosome [26] and the highly repetitive nature of the $\mathrm{h} 39$ region complicate the molecular and genetic investigations of this chromosomal region.

Many transposon relics map at both sides of the Bari1 cluster in the h39 region of the mitotic chromosomes of D. melanogaster [27]. A direct duplication of a $596 \mathrm{bp}$ sequence identified upstream and downstream of the Baril cluster is of particular interest. We hypothesized that this short duplication could be the signature of the transposition-mediated origin of the Bari1 cluster (as also hypothesized for the minor X-linked Bari1 cluster [25]). Alternatively, it could have a functional role in the h39 locus or in the heterochromatin [27]. Since the first hypothesis seems unreliable (due to the size incompatibility and outcome of the transposition event), in this work we tested the hypothesis that the above-described $596 \mathrm{bp}$ sequence could have acquired a new function in the heterochromatin through the binding of a chromatin protein. Here, we present evidence that the ribosomal protein Rpl22 
binds DNA in vitro, which suggests the possibility that it could be recruited as chromatin protein. The CG7434 gene, which encodes RpL22 protein, maps on the $\mathrm{X}$ chromosome. Three additional genes are present within the coding region of RpL22, two encoding snoRNAs (CR34590 and CR33918) and one encoding a ncoRNA (CR42491). This structure complicates the genetic analysis of the locus, and, in fact, no genetic studies have been performed focusing on this gene. At least two post-translational modification events have been characterized, involving phosphorylation of the Ser 289 and Ser290 residues of the RpL22 in Drosophila [28]. Among RPs, some members of the RpL22e family have unique structural features and several, apparently unrelated, possible functions. The Drosophila Rpl22 has additional Ala-, Lys- and Pro-rich sequences at the amino terminus, which resembles the carboxyl-terminal portion of histone $\mathrm{H} 1$ and histone $\mathrm{H} 5$ that have been demonstrated to be important in genome stability [29]. For this reason, it has been already hypothesized that Drosophila L22 might have two functions, namely, the role of DNA-binding similar to histone $\mathrm{H} 1$ and the role of organizing the ribosome [30]. Moreover, as hypothesized in previous works, any potential biological difference between Rpl22 and Rpl22-like proteins should be ascribed to the presence of the extra N-terminal domain of Rpl22, which can be the target of post-translational modifications [31].

We also have evidence that Rpl22 enters into the nucleus of different cell types, in addition to what was demonstrated previously in the male germline cells [32]. The possible implications in the stability of a specific heterochromatin region are discussed.

\section{Materials and Methods}

\subsection{Plasmids Construction}

The Doc5 fragment flanking the Bari1 cluster was PCR-amplified from the purified DNA of the BACR16M08 clone (described in [25]) using specific primers containing EcoRI adapters at the $5^{\prime}$ end. The PCR fragment was cloned into the EcoRI site of the pGEM-T vector (Promega) and verified by Sanger sequencing.

\subsection{PCR Amplification}

Primers used for PCR amplification are reported in Table 1.

Table 1. List of primers used in this study.

\begin{tabular}{|c|c|c|}
\hline Primer & Sequence & Usage \\
\hline ADread & 5'-CTATTCGATGATGAAGAT-3' & sequencing \\
\hline pACT2seq & 5'-TACCACTACAATGGATG-3' & sequencing \\
\hline pACT2 up & 5'-CTATTCGATGATGAAGATACCCCACCAAACCC-3' & Amplification/cloning \\
\hline pACT2 low & 5'-GTGAACTTGCGGGGTTTTTCAGTATCTACGAT-3' & Amplification/cloning \\
\hline His1_up & 5'-GAGGCCCTTTCGTCTTCAA-3' & Amplification/cloning \\
\hline His1_low & 5'-CTAGGGCTTTCTGCTCTGTCATCT-3' & Amplification/cloning \\
\hline Doc5_up & 5'-ACGGCTATTATTGTTTCTTATTGCT-3' & Amplification/cloning \\
\hline Doc5_low & 5'-TTATCСТCATCССТTATCСТАTGT-3' & Amplification/cloning \\
\hline pETup & 5'-CACCATGGCTTACCCATA-3' & Amplification/cloning \\
\hline pETlow & 5'-ATAAAAGAAGGCAAAACGATG-3' & Amplification/cloning \\
\hline H5low & 5'-CTAACGCAGCACGTTCTTCTT-3' & Amplification/cloning \\
\hline L22up & 5'-CACCAAGGTGGTCAAGAAGAA-3' & Amplification/cloning \\
\hline
\end{tabular}

\subsection{One Hybrid Screening}

The one hybrid screening was performed using the Matchmaker One-Hybrid System (Clontech, Kyoto, Japan) following the manufacturer recommendations.

A Drosophila embryonic cDNA library (cDNA pool from 0-21 h embryos of the Canton$\mathrm{s}$ strain) in the PACT2 vector (Clontech) was used for the yeast one-hybrid screens. 
The Doc5 sequence was subcloned into the pHISi-1 vector at the EcoRI site and into the pLacZi vector. Both plasmids were linearized using either BamHI (pHISi-1) or NcoI (pLacZi) and transformed in the YM4271 S. cerevisiae strain using the TRAFO system [33]. Recombinant colonies, carrying the integrated constructs, were selected onto selective SD medium lacking either histidine (pHISi-1 vector) or uracil (pLacZi vector).

The background expression of the Lac $Z$ reporter was determined by a standard $\beta$ galactosidase assay. Colonies were transferred to Whatman filter paper discs and lysed with liquid nitrogen. Filters were then exposed to Z-buffer $\left(\mathrm{Na}_{2} \mathrm{HPO}_{4} \cdot 7 \mathrm{H}_{2} \mathrm{O} 60 \mathrm{mM}\right.$, $\mathrm{NaH}_{2} \mathrm{PO}_{4} \cdot \mathrm{H}_{2} \mathrm{O} 40 \mathrm{mM}, \mathrm{KCl} 10 \mathrm{mM}, \mathrm{MgSO} 41 \mathrm{mM}, \beta$-mercaptoethanol $50 \mathrm{mM}, \mathrm{pH}$ 7) containing X-gal (5-bromo-4-chloro-indolyl-b-D-galactopyranoside $0.33 \mathrm{mg} / \mathrm{mL}$ ). Only clones without LacZ basal expression in $8 \mathrm{~h}$ were selected for further analyses. These clones were further transformed to integrate the linearized pHisi-1 vector. Background expression of the His cassette was found to be inhibited by $15 \mathrm{mM}$ 3-AT.

\subsection{Protein Expression and Purification}

The plasmid sets used to express proteins in E. coli (pET/RpL22 for the full-length protein expression; $\mathrm{pET} / \mathrm{H} 5$ for the H1-H5 domain expression; pET/L22 for the ribosomal domain expression) were constructed by PCR amplification of either the full-length, the $5^{\prime}$-terminal or the $3^{\prime}$-terminal part of the cDNA and subsequent cloning into the pET-200 vector.

Plasmids were transformed in chemically competent E. coli (BL21-DE3), and the cultures were induced with $1 \mathrm{mM}$ IPTG at a cell density equivalent to $0.5 \mathrm{OD}_{600}$ and maintained for $2.5 \mathrm{~h}$ at $37^{\circ} \mathrm{C}$. Cells were sonicated in $25 \mathrm{mM} \mathrm{HEPES} \mathrm{(pH} \mathrm{7.5),} 1 \mathrm{M} \mathrm{NaCl}$, $15 \%$ glycerol, $0.25 \%$ Tween $20,2 \mathrm{mM} \beta$-mercaptoethanol, and $1 \mathrm{mM}$ PMSF. A total of $10 \mathrm{mM}$ imidazole ( $\mathrm{pH} 8.0$ ) was added to the soluble fraction before it was mixed with Ni-NTA resin (Qiagen, Hilden, Germany) according to the manufacturer's recommendations. The resin was washed with sonication buffer containing $30 \%$ glycerol and $50 \mathrm{mM}$ imidazole. Bounded proteins were eluted with sonication buffer containing $300 \mathrm{mM}$ imidazole and dialyzed overnight against sonication buffer without imidazole. Purified proteins were analyzed on $12 \%$ SDS-polyacrylamide gel. Protein concentration was determined using the Protein Assay ESL Kit (Roche Basel, Switzerland).

\subsection{Electrophoretic Mobility Shift Assay (EMSA)}

In total, $5 \mu \mathrm{g}$ of the $\mathrm{pT} /$ Doc5 plasmid was EcoRI-digested and the released fragment was gel-purified using the QIAquick Gel Extraction Kit (Qiagen). A filling-in reaction was performed to end-label the target DNA. A total of $50 \mathrm{ng}$ of the eluted fragment was incubated with $\left[\alpha^{32}\right.$ P]ATP (Perkin Elmer, Waltham, MA, USA), 1X Klenow reaction buffer and $2 \mathrm{U}$ of Klenow fragment (Roche, Basel, Switzerland).

Labeled fragments were purified using Sephadex G50 exclusion chromatography columns.

A total of $2 \mathrm{ng}$ of the labeled fragment was incubated with the appropriate protein (either the full-length Rpl22, the H1-H5 domain or the ribosomal domain) in binding buffer as described in [34] (25 mM HEPES, pH 7.6, $50 \mathrm{mM} \mathrm{NaCl}, 1 \mathrm{mM}$ EDTA, $1 \mathrm{mM}$ DTT, $0.1 \mathrm{mg} / \mathrm{mL}$ BSA, $2.5 \mathrm{mM}$ spermidine, 10\% glycerol, and $0.1 \mathrm{mg} / \mathrm{mL}$ poly (dI-dC). Competition experiments were performed using either linear pUC19 (SmaI linearized) or sonicated $\lambda$ phage DNA (200-1000 bp size range enrichment). The binding reaction was started by adding the protein extract and incubated for $20 \mathrm{~min}$ at $25^{\circ} \mathrm{C}$, then loaded directly onto $5 \%$ polyacrylamide (75:1 acrylamide:bisacrylamide) pre-run gel in $40 \mathrm{mM}$ Tris-acetate, $2.5 \mathrm{mM}$ EDTA (pH 7.8). Gels were run for $4.5 \mathrm{~h}$ at $4{ }^{\circ} \mathrm{C}$ at $10 \mathrm{~V} / \mathrm{cm}$ and dehydrated using a gel-dryer. DNA-protein complexes were visualized by autoradiography using a STORM phosphorimager (Molecular Dynamics).

\subsection{Fluorescence In Situ Hybridization and Immunofluorescence on Polytene Chromosomes}

Fluorescence in situ hybridization experiments on polytene chromosomes were performed as described in [35]. Polytene chromosomes were prepared from third instar larvae 
of $D$. simulans and D. sechellia, reared on standard cornmeal medium at $18{ }^{\circ} \mathrm{C}$. Salivary glands were dissected in PBS using a pair of dissection needles, fixed in $40 \%$ acetic acid, and squashed onto microscopy slides. Probes were labeled using the nick translation method with Cy3-dUTP, hybridized overnight at $37^{\circ} \mathrm{C}$.

Digital images were obtained using an Olympus epifluorescence microscope equipped with a cooled CCD camera. Gray scale images, recording Cy3 and DAPI fluorescence, were obtained separately using specific filters and were pseudo colored and merged to obtain the final image using the Adobe Photoshop software.

Immunodetection experiments of Rpl22 and fibrillarin on polytene chromosomes of the Oregon-R (wild type) were performed according to James et al. [36] using the polyclonal primary anti-Rpl22 antibody (diluted 1:50) raised in rabbit (Invitrogen Carlsbad, CA, USA, Minervini et al. submitted) and the monoclonal (G-8sc-374022 Santa Cruz Biotechnology Inc., Dallas, TX, USA) anti-fibrillarin antibody raised in mouse. An FITC (fluorescein isothiocyanate)-conjugated anti-rabbit Ig (whole antibody) raised in sheep (diluted 1:20) and the Alexa Fluor 488 goat anti-mouse antibody (Life Technologies, Carlsbad, CA, USA, 1:200 dilution) were used as secondary antibodies. Following incubation, the slides were washed three times in PBS, stained with DAPI (4,6-diamidino-2-phenilindole) at $0.01 \mu \mathrm{g} / \mathrm{mL}$ and mounted in anti-fading medium. Immunodetection on S2R+ cells were performed as previously described in $[20,21]$ using the above-described antibodies.

\subsection{Other Methods}

Sequencing of the cloned fragments was performed at the BMR Genomics sequencing facility (Padova, Italy).

Global alignments were performed using DNA Strider [37]. Local alignments were performed using BLAST at the NCBI website.

NLS signals were searched with cNLS Mapper (http:/ /nls-mapper.iab.keio.ac.jp/cgibin/NLS_Mapper_form.cgi (accessed on 1 March 2021)) [38] using a cutoff score $=7$ in the entire protein sequence, and with Nucpred (https:/ / nucpred.bioinfo.se/cgi-bin/single.cgi (accessed on 2 March 2021)) [39].

\section{Results}

We have previously identified a 596 bp DNA sequence duplication (formerly named DRM8) at both sides of the Bari1 cluster in the heterochromatin of $2 \mathrm{R}$ chromosome of D. melanogaster [27]. Specifically, this repetitive sequence maps in the h39 region, and it has been proven lately to be a remnant of the Doc5/Porto1 element, a highly repeated non-LTR retrotransposon in the heterochromatin of $D$. melanogaster [40]. The similarity between the DRM8 sequence and the reference Doc5/Porto1 element is shown in Figure 1. Hereafter, we will refer to this sequence as Doc5.

Several copies of the Doc5 can be found in the reference genome of D. melanogaster (see Table 2). In silico analyses reveal that Doc5 maps exclusively in the constitutive heterochromatin of the two major autosomes of D. melanogaster, including the centromere, as well as at the eu-heterochromatin transition.

The heterochromatic localization of the Doc5 element is also a conserved feature in closely related species of the melanogaster complex, such as D. simulans and D. sechellia, as demonstrated by the results of FISH experiments on polytene chromosomes (Figure 2). 


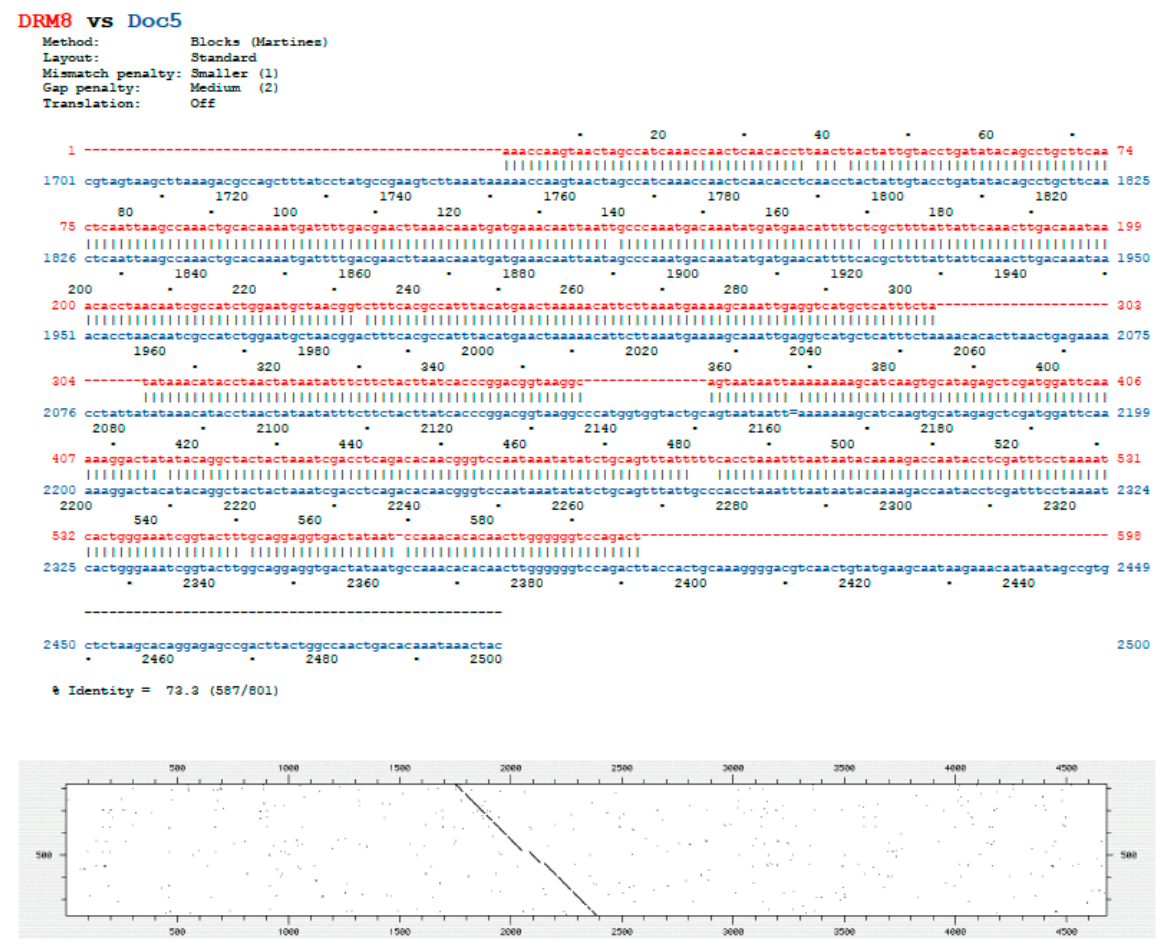

Window $=7$; stringency $=7$

Figure 1. Comparison of the Doc5 reference sequence and the $596 \mathrm{bp}$ sequence identified at both sides of the Bari1 cluster in the h39 region of the chromosome 2 of D. melanogaster. The global sequence alignment and the dot-plot comparison are shown.

Table 2. The distribution of the Doc5 transposon in the D. melanogaster genome

\begin{tabular}{|c|c|c|c|c|c|c|c|c|}
\hline $\begin{array}{c}\text { Subject } \\
\text { Accession }\end{array}$ & Start & End & Chromosome & $\%$ Identity & $\begin{array}{l}\text { Alignment } \\
\text { Length }\end{array}$ & Evalue & Bit Score & $\begin{array}{l}\text { Chromosome } \\
\text { Map Position }\end{array}$ \\
\hline NT_033779.5 & $23,430,152$ & $23,429,509$ & $2 \mathrm{~L}$ & 85.891 & 645 & 0 & 643 & h35-36 \\
\hline NT_033779.5 & $23,037,532$ & $23,037,717$ & $2 \mathrm{~L}$ & 91.237 & 194 & $2.03 \times 10^{-67}$ & 257 & h35-36 \\
\hline NW_001845128.1 & 3990 & 4435 & 2CEN & 100 & 446 & 0 & 824 & deep het \\
\hline NW_001845128.1 & 3875 & 3990 & 2CEN & 100 & 116 & $1.24 \times 10^{-54}$ & 215 & deep het \\
\hline NW_001844967.1 & 11,017 & 10,572 & $2 \mathrm{CEN}$ & 100 & 446 & 0 & 824 & deep het \\
\hline NW_001844967.1 & 11,132 & 11,017 & 2CEN & 100 & 116 & $1.24 \times 10^{-54}$ & 215 & deep het \\
\hline NW_007931075.1 & 7023 & 6491 & $2 \mathrm{CEN}$ & 82.655 & 565 & $2.43 \times 10^{-121}$ & 436 & deep het \\
\hline NW_007931075.1 & 9914 & 9382 & 2CEN & 82.655 & 565 & $2.43 \times 10^{-121}$ & 436 & deep het \\
\hline NT_033778.4 & 396,636 & 397,234 & $2 \mathrm{R}$ & 99.332 & 599 & 0 & 1083 & h41-h44 \\
\hline NT_033778.4 & 165,422 & 164,833 & $2 \mathrm{R}$ & 95.326 & 599 & 0 & 942 & h41-h44 \\
\hline NT_033778.4 & 74,075 & 74,637 & $2 \mathrm{R}$ & 92.833 & 586 & 0 & 824 & h41-h44 \\
\hline NT_033778.4 & 298,134 & 297,689 & $2 \mathrm{R}$ & 100 & 446 & 0 & 824 & h41-h44 \\
\hline NT_033778.4 & 872,342 & 871,810 & $2 \mathrm{R}$ & 82.655 & 565 & $2.43 \times 10^{-121}$ & 436 & h41-h44 \\
\hline NT_033778.4 & 875,233 & 874,701 & $2 \mathrm{R}$ & 82.655 & 565 & $2.43 \times 10^{-121}$ & 436 & h41-h44 \\
\hline NT_033778.4 & $1,413,093$ & $1,413,384$ & $2 \mathrm{R}$ & 91.333 & 300 & $2.47 \times 10^{-111}$ & 403 & h45 \\
\hline NT_033778.4 & $3,518,328$ & $3,518,018$ & $2 \mathrm{R}$ & 88.179 & 313 & $1.95 \times 10^{-97}$ & 357 & h41-h44 \\
\hline NT_033778.4 & $5,012,337$ & $5,012,064$ & $2 \mathrm{R}$ & 82.818 & 291 & $4.43 \times 10^{-59}$ & 230 & h46 \\
\hline NT_033778.4 & 298,249 & 298,134 & $2 \mathrm{R}$ & 100 & 116 & $1.24 \times 10^{-54}$ & 215 & h41-h44 \\
\hline NT_033778.4 & $5,012,596$ & $5,012,448$ & $2 \mathrm{R}$ & 84.302 & 172 & $4.59 \times 10^{-34}$ & 147 & h46 \\
\hline NT_037436.4 & $24,877,579$ & $24,878,162$ & $3 \mathrm{~L}$ & 87.081 & 596 & 0.0 & 656 & h49 \\
\hline NT_037436.4 & $24,914,416$ & $24,913,834$ & $3 \mathrm{~L}$ & 86.745 & 596 & 0.0 & 645 & h49 \\
\hline
\end{tabular}


Table 2. Cont.

\begin{tabular}{|c|c|c|c|c|c|c|c|c|}
\hline $\begin{array}{c}\text { Subject } \\
\text { Accession }\end{array}$ & Start & End & Chromosome & $\%$ Identity & $\begin{array}{l}\text { Alignment } \\
\text { Length }\end{array}$ & Evalue & Bit Score & $\begin{array}{l}\text { Chromosome } \\
\text { Map Position }\end{array}$ \\
\hline NT_037436.4 & $24,944,076$ & $24,944,602$ & $3 \mathrm{~L}$ & 87.199 & 539 & $2.93 \times 10^{-170}$ & 599 & h49 \\
\hline NT_037436.4 & $24,461,859$ & $24,462,331$ & $3 \mathrm{~L}$ & 85.443 & 474 & $6.71 \times 10^{-127}$ & 455 & h47 \\
\hline NT_037436.4 & $23,664,082$ & $23,663,846$ & $3 \mathrm{~L}$ & 94.583 & 240 & $9.00 \times 10^{-101}$ & 368 & $80 \mathrm{~F} 9$ \\
\hline NT_037436.4 & $23,663,844$ & $23,663,639$ & $3 \mathrm{~L}$ & 92.754 & 207 & $1.20 \times 10^{-79}$ & 298 & $80 \mathrm{F9}$ \\
\hline NT_037436.4 & $25,490,094$ & $25,490,271$ & $3 \mathrm{~L}$ & 94.382 & 178 & $2.02 \times 10^{-72}$ & 274 & h49-h50 \\
\hline NT_037436.4 & $27,913,043$ & $27,913,159$ & $3 \mathrm{~L}$ & 93.277 & 119 & $7.57 \times 10^{-42}$ & 172 & h51 \\
\hline NT_037436.4 & $24,502,780$ & $24,502,891$ & $3 \mathrm{~L}$ & 92.035 & 113 & $2.12 \times 10^{-37}$ & 158 & h48 \\
\hline NT_037436.4 & $27,912,886$ & $27,913,038$ & $3 \mathrm{~L}$ & 81.609 & 174 & $2.15 \times 10^{-27}$ & 124 & h51 \\
\hline NT_033777.3 & 646,928 & 646,337 & $3 R$ & 86.612 & 605 & 0.0 & 649 & h54-h56 \\
\hline NT_033777.3 & $4,042,323$ & $4,042,066$ & $3 R$ & 94.961 & 258 & $6.86 \times 10^{-112}$ & 405 & $81 \mathrm{~F}$ \\
\hline NT_033777.3 & $1,401,453$ & $1,401,023$ & $3 \mathrm{R}$ & 83.991 & 431 & $1.50 \times 10^{-103}$ & 377 & h54-h56 \\
\hline NT_033777.3 & $4,050,664$ & $4,050,455$ & $3 R$ & 95.238 & 210 & $3.28 \times 10^{-90}$ & 333 & $81 \mathrm{~F}$ \\
\hline NT_033777.3 & $3,992,575$ & $3,992,365$ & $3 R$ & 94.787 & 211 & $1.53 \times 10^{-88}$ & 327 & $81 \mathrm{~F}$ \\
\hline NT_033777.3 & $4,039,954$ & $4,039,769$ & $3 R$ & 91.710 & 193 & $1.57 \times 10^{-68}$ & 261 & $81 \mathrm{~F}$ \\
\hline NT_033777.3 & $2,453,123$ & $2,453,400$ & $3 R$ & 80.357 & 280 & $4.53 \times 10^{-44}$ & 180 & h56 \\
\hline NT_033777.3 & $2,453,399$ & $2,453,508$ & $3 R$ & 92.793 & 111 & $5.90 \times 10^{-38}$ & 159 & h56 \\
\hline NW_001845051.1 & 2554 & 2831 & UNK & 80.357 & 280 & $4.53 \times 10^{-44}$ & 180 & deep het \\
\hline NW_001845051.1 & 2830 & 2934 & UNK & 89.189 & 111 & $1.29 \times 10^{-29}$ & 132 & deep het \\
\hline
\end{tabular}

The Doc5 sequence (596 bp) was used as a query in BlastN analyses against the D. melanogaster reference genome (Release 6). The approximate map positions in the rightmost column were inferred by comparison with the data in [12]. Only alignments longer than 100 bases are shown. Deep het: deep heterochromatin. UNK: unknown map position.

\section{D.sechellia}

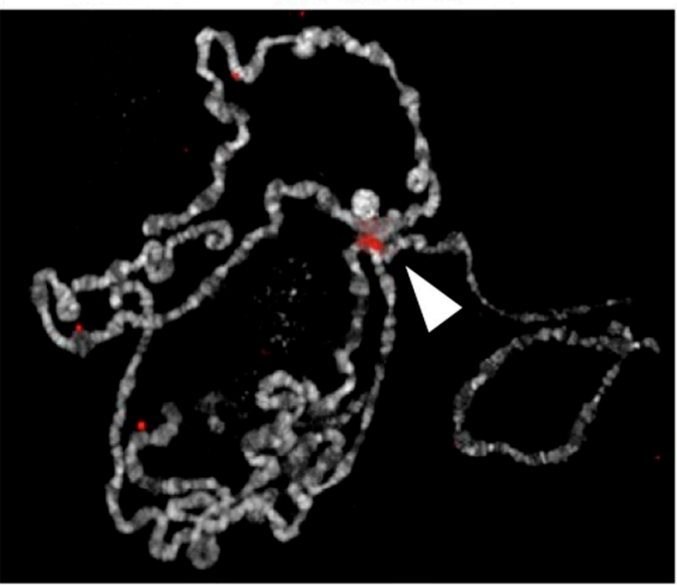

D.simulans

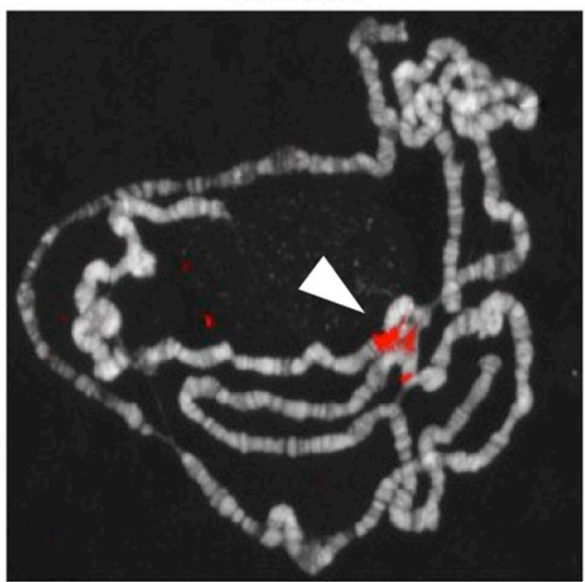

Figure 2. The distribution of the Doc5 transposon was analyzed by FISH in the genome of $D$. sechellia (left panel) and $D$. simulans (right panel), two species closely related to D. melanogaster. The Doc5 fragment cloned from the h39 region (596bp sequence) was used as probe. Arrowheads point to the chromocenter.

The hybridization signals in the chromocenter and at the eu-heterochromatin transition on the chromosome arms (Figure 2) clearly highlight a heterochromatin-specific pattern of Doc5, which is conserved in D. simulans and D. sechellia. The positional conservation of a transposon relic might indicate its possible functional or structural role, such as the determination of the chromatin identity domains or the implication in transcriptional processes.

The evolutionary conservation of the heterochromatic pattern and the high degree of sequence identity of the Doc5 fragment duplicated at both sides of the Bari1 cluster prompted us to hypothesize a possible structural role of the Doc5 sequence both in the heterochromatin of D. melanogaster and in the identity of the h39. It was previously 
suggested that the preservation of a repetitive non-coding DNA sequence, especially in the heterochromatin, could be promoted with the aid of stabilizing binding proteins [41], such as chromatin proteins. To test this hypothesis, we performed a One-Hybrid System assay aimed at the identification of proteins that potentially interact with the Doc5 fragment.

The double selection method (i.e., His prototrophy and positivity to the $\beta$-galactosidase test) applied to identify positive clones ensures that the false positive rate is minimized.

Twenty-four positive clones, selected on selective media lacking histidine, were further tested with the $\beta$-galactosidase activity (Table S1). Many of these clones turned rapidly blue upon $\beta$-galactosidase testing ( $3-5 \mathrm{~h}$ ). However, a large fraction ( $46 \%$ ) of such clones matched to Rpl22 transcripts after Sanger sequencing and BLASTN analysis. Based on the fastness of color turning (the smallest the better) and the relative abundance of positive clones, we chose Rpl22 as the candidate for further investigations.

The positive clones obtained from the first round of screening were further validated by independent transformation of the isolated plasmids into the bait-containing yeast strains (i.e., yeast strains containing the Doc5-His and Doc5-lacZ cassette, data not shown) to confirm the bait-pray interaction.

To further solidify this result, we assayed the Rpl22-Doc5 interaction in vitro. The Rpl22 protein was expressed and purified in E. coli and used for in vitro binding assays in order to test its ability to bind an end-labeled Doc5 fragment (see Materials and Methods).

As can be observed in Figure 3 (lanes 3-5), increasing amounts of purified protein led to a slower migration in a polyacrylamide gel, suggesting the formation of progressively slower DNA-protein complexes. In our hands, $3 \mu \mathrm{g}$ of the protein extract led to the formation of the slowest DNA-protein complex. This pattern could be explained by either the presence of multiple binding sites in the target or by the possible formation of multimeric protein complexes that bind the target fragment.

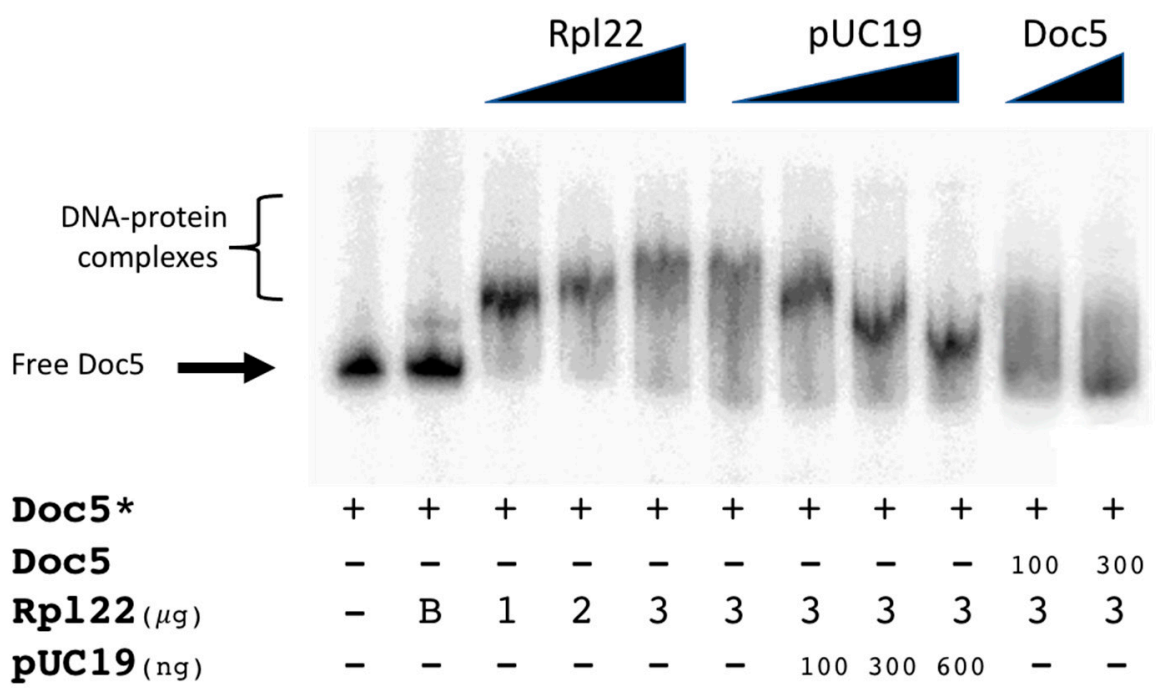

Figure 3. The binding of Rpl22 to Doc5. The amount of labeled fragment (Doc5 *, Figure 3) in each lane is $3 \mathrm{ng}$. The amounts of unlabeled specific competitor (ng of Doc5), Rpl22 ( $\mu \mathrm{g}$ ), and unlabeled non-specific competitor (ng of linearized pUC19) are indicated in the figure legend under the respective lanes. Increasing amounts of purified Rpl22 protein (lanes 3-5) and non-specific (lanes 6-9) and specific (lanes 10-11) competitors are indicated on the top by triangles. A negative control (lane 2) was performed following the incubation of the Doc5-labeled probe with $3 \mu \mathrm{g}$ of non-induced E. coli (BL21 strain) lysate (indicated with B). The labeled fragments are indicated with an asterisk $\left(^{*}\right)$.

The observed protein binding is specific and reversible, as demonstrated by the competition assays in Figure 3. While a 200-fold amount of unspecific competitor is not sufficient to disrupt the Rp122-Doc5 interaction (Figure 3, lanes 6-9), a 30-fold amount of target fragment completely disrupts the observed DNA-protein binding (Figure 3, lanes 10-11). Additional controls to assess the specificity of the binding were performed 
using either an unrelated DNA fragment, or using a different non-specific competitor DNA (Figure S1).

We next investigated whether the two domains of Rpl22 could differentially contribute to the observed DNA-protein interaction. The H1-H5 domain and the ribosomal domain were independently tested in EMSA assays for their ability to interact with Doc5. As can be observed in Figure 4, only the H1-H5 domain retains the ability to bind the Doc5 fragment tested (Figure 4, lane 3), whereas the ribosomal domain does not (Figure 4, lane 2) if compared to the binding observed for the wild-type Rpl22 protein (Figure 4, lane 4). Similar to what observed for the wild-type protein (Figure 3, lanes 3-5), the H1-H5 domain interacts with the Doc5 sequence in a dose-dependent manner (Figure 4B).

A

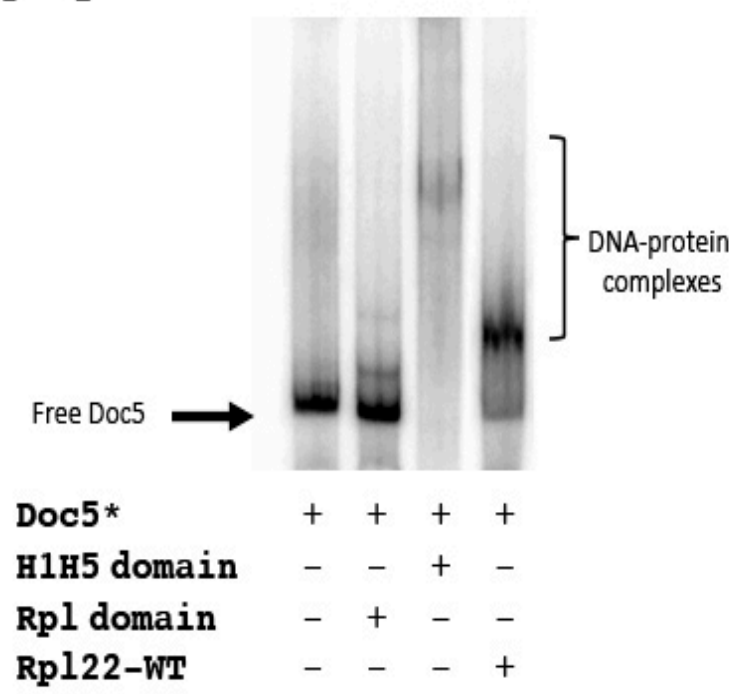

Doc5* H1H5 domain

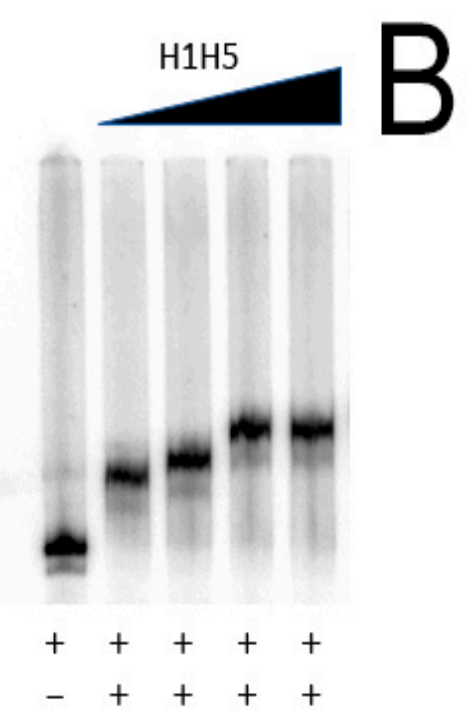

Figure 4. Dissection of the DNA-binding domain of Rpl22 in vitro. Labeled fragments are indicated with an asterisk $\left({ }^{*}\right)$. (A) EMSA analysis of the ribosomal and the histone-like domains of Rpl22. (B) EMSA analysis of the histone-like domain. A total of $3 \mu \mathrm{g}$ of the Rpl22 (WT) and $1.5 \mu \mathrm{g}$ of the H1-H5 and ribosomal domains were used to maintain the unaltered DNA:protein molar ratio. A schematic representation of the two main domains of Rpl22 protein is depicted at the top of the figure. Asterisk indicates that the fragment is labelled.

To further investigate the possible role of Rpl22 in the chromatin dynamics, we tested the Rpl22 protein localization in both D. melanogaster cultured cells, in order to check whether the protein co-localizes with chromosomes. We performed immunofluorescence localization of the native Rpl22 protein on polytene chromosomes of the Oregon-R wildtype strain and inn cultured S2R+ cells, using a polyclonal antibody raised against the Rpl22 protein.

The results obtained (Figure 5) clearly show that Rpl22 localizes to the nuclei, with a marked nucleolar localization that has been further confirmed by co-localization with the nucleolar marker fibrillarin, (Figure S2) both in salivary gland cells (Figure 5A) and in cultured cells (Figure 5B), without any additional evidence of localization to chromatin.

In silico prediction of the nuclear localization of Rpl22 using cNLS Mapper [38] suggests its nuclear localization, with the best scoring NLS signal (score 7/7) mapped at position 234. A similar search, using NucPred [39] as an alternative algorithm, returned the sequence GKGQKKKK (position 181, score 0.28; a 0.30 threshold corresponds to $77 \%$ sensitivity and $55 \%$ specificity). 

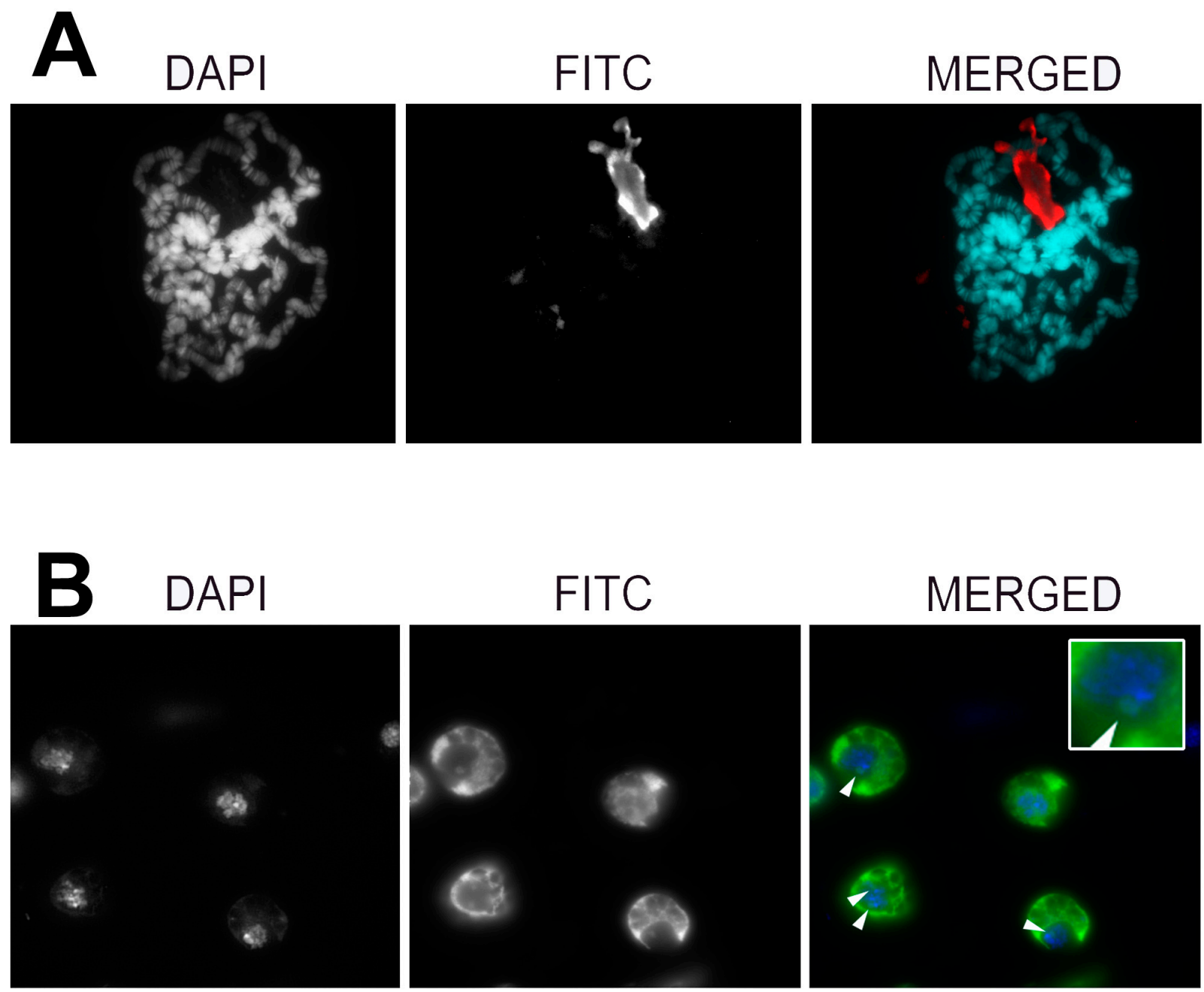

Figure 5. Pattern of subcellular immunolocalization of Rpl22 in D. melanogaster salivary gland nuclei (A) and in cultured S2R+ cells (B). White arrowheads point to nucleoli. A magnified detail of the nucleolar co-localization is reported in the inset. Additional details on the localization of Rp122 to nucleoli are given in Figure S2.

In the absence of additional experimental evidence, the possible role of Rpl22 in the heterochromatin can be inferred from interactomic data obtained in previously published works. Out of the ninety-one RpL22-interacting proteins that are annotated in FlyBase, 13 are non-RPs. Notably, 12 out of the 13 interacting proteins are not directly linked with the translational machinery.

Rpl22 interacts with protein involved in heterochromatin organization (vig and vig2 [42,43]), piRNA biogenesis (Fmr1 and its associated miRNA, bantam [44]), and transcriptional repression (Ago1 and Ago2 [42]) (reported in Table 3). Such interactions further suggest the involvement of Rpl22 in chromatin determination and transcriptional pathways, supporting our hypothesis.

Table 3. Rpl22 interacting proteins involved in heterochromatin functions. Information retrieved from Flybase (last accessed August 2021).

\begin{tabular}{ccccc}
\hline Gene Name & FlyBase ID & Function & Inferred by & Reference \\
\hline vig & FBgn0024183 & Heterochromatin organization & Co-IP & {$[42]$} \\
\hline AGO1 & FBgn0262739 & transcriptional repression & Co-IP & {$[42]$} \\
\hline AGO2 & FBgn0087035 & transcriptional repression & Co-IP & {$[42]$} \\
\hline
\end{tabular}


Table 3. Cont.

\begin{tabular}{ccccc}
\hline Gene Name & FlyBase ID & Function & Inferred by & Reference \\
\hline vig2 & FBgn0046214 & Heterochromatin organization & Mass-spec & {$[43]$} \\
\hline Fmr1 & FBgn0028734 & piRNA biogenesis & Co-IP & {$[42]$} \\
\hline ban & FBgn0262451 & piRNA biogenesis & Co-IP & {$[42]$} \\
\hline esi2 & FBgn0285992 & Unknown & Co-IP & {$[42]$} \\
\hline smt3 & FBgn0264922 & mitosis & Co-IP & {$[31]$} \\
\hline
\end{tabular}

\section{Discussion}

The stabilization of large chromosomal domains containing extended repeat blocks essentially depends on the chromatin architecture that wraps these loci. Both the Encode [5] and modEncode [45] projects have had a leading role in the determination of the genomewide chromatin status in $H$. sapiens and model organisms, respectively. The outcome of these huge projects led to the birth of epigenomics that aims to link cell-type-specific gene expression to chromatin structure. The specific features of chromatin domains are also of critical importance for genome evolution since the propensity of certain loci to be converted and relocated from the euchromatin to the heterochromatin is probably determined by the ancestral epigenetic marks [46]. For this reason, profound knowledge of chromatin dynamics is fundamental in the determination of the evolutionary trajectories that chromosomes follow.

However, chromatin is a highly dynamic biological entity, and for this reason, it is difficult to provide a definitive and exhaustive description. Unbiased approaches, i.e., not focused on a particular developmental stage or specific tissue, allow for a near-to-complete characterization of chromatin-associated proteins. It follows that the elucidation of the changing state of chromatin in the most diverse cellular types is of particular importance toward the complete understanding of physiological and pathological conditions [47].

Here, we report that a ribosomal protein binds the Doc5 transposon, a non-autonomous TE family enriched in the heterochromatin of D. melanogaster and closely related species [48], providing in vitro experimental evidence for a functional interaction of Rpl22 with DNA, and possibly to chromosome and chromatin. In Drosophila, the direct binding of protein to TEs, especially involving retrotransposons, has been previously reported [49-51]. In a yeast one-hybrid assay, we probed a D. melanogaster expression library with Doc5 as bait and found Rpl22 as the best candidate interacting protein. We have further validated the DNA-protein interaction with a series of EMSA experiments that confirmed the results of the experiments in yeast. We further demonstrated that the NH-terminal domain (H1-H5 domain) of the protein is both necessary and sufficient to bind DNA. Furthermore, the assays performed in vitro show that the Doc5-Rpl22 interaction depends on the amount of protein input. We cannot dismiss the hypothesis that this behavior could depend both on the presence of multiple binding sites on the target (which we have not investigated), and on the ability of Rpl22 to multimerize or to form homogeneous aggregates. In addition, the net charge density of the expressed H1-H5 domain is greater than that of the wild-type Rpl22 protein (27.14/15.8 KDa vs. 36.51/30.6 KDa, respectively, at $\mathrm{pH}=7$ ), which can account for the increased shift of the H1-H5/Doc5 complex if compared to the wild-type Rpl22/Doc5 complex (Figure 4).

What is the relevance of our findings? Our results let us hypothesize that Rpl22 could have a potential role in the organization of chromatin, possibly in heterochromatin, and this hypothesis is supported by several studies reporting that RPs are linked to biological processes occurring in the nucleus [52]. RPs have been found associated at transcription sites in Drosophila polytene chromosomes. This unexpected finding suggested that ribosomal subunits could be associated with nascent mRNAs [53]. An additional study in Saccharomyces cerevisiae showed that RPs bind to noncoding RNA genes, suggesting that the RPs-RNA association might be independent of the translatability of the transcript and 
might involve free RPs that are not assembled into ribosomes [54]. Several other examples of RPs with extra ribosomal functions at transcription sites have been reported to date. Some RPs auto-regulate their expression by affecting translation, splicing, or transcription by interacting with their mRNA, or promoter [55-57]. RPs are also able to interact with transcription factors at the promoters of genes. RpL11 binds the oncoprotein c-MYC at the promoter of c-MYC target genes [58,59], RpS3 is a subunit of the NF- $\mathrm{kB}$ DNA-binding complex involved in chromatin binding and transcription regulation of specific genes [60]. RpS3 phosphorylation at serine 209 by IKKb is crucial for RPS3 nuclear localization in response to activating stimuli [61].

Rpl22 is a ribosomal protein with a prevailing cytoplasmic localization. Past-published reports claimed that Rpl22 also localizes to the nucleus of Drosophila cells. Ni and collaborators [62] demonstrated that Rpl22 expressed at endogenous levels localizes in the nucleus of Drosophila Kc (embryo-derived) and cl-8 (derived from imaginal discs) cell cultures, and it is associated with chromatin, resulting in gene suppression. Immunofluorescent staining and chromatin immunoprecipitation (ChIP) analyses demonstrated that RpL22 and $\mathrm{H} 1$ are both associated with condensed chromatin. In the same study, it was demonstrated that the overexpression of RpL22 caused the transcriptional repression of two-thirds of the genes suppressed by histone H1. By contrast, RpL22 depletion caused the upregulation of the transcription of several tested genes, supporting a role for RpL22 as transcriptional repressor [62]. These observations imply the involvement of Rpl22 in global transcriptional processes.

However, Rpl22 has not been previously identified in surveys aimed at the identification of chromatin structure. This can be due to an experimental bias when searching histone modifications [63]. On the other hand, unbiased studies have been focused on euchromatic genomic regions only [64]. Conversely, our approach was based on the search of proteins that interact with a heterochromatic sequence, and our results support a role of Rpl22 in the chromatin. To what extent Rpl22 could participate in the determination of chromatin domains remains to be determined. Another potential implication of our findings concerns the possible role of the non-autonomous Doc5 transposon in the D. melanogaster genome. Non-autonomous TEs often acquire new functions in complex genomes, over evolutionary time. Many examples of evolutionarily inactive TEs that have been co-opted, exapted, or domesticated are described in the scientific literature $[65,66]$.

It has been demonstrated that Doc5 is under the control of the piRNA pathway $[67,68]$. Since no potentially active Doc5 copies are found, these findings suggest that the short RNAs generated from Doc5 could have alternative roles in the regulation of gene expression, or alternatively in the regulation of the transposition of other, unrelated, TEs.

Alternatively, Doc5 could mark a chromatin domain with a structural function that prevents the excessive expansion of the Baril cluster. This hypothesis could be extended to other species-specific heterochromatic repeats, since the Baril cluster is unique to the D. melanogaster species, while Doc5 is present in the genome of sibling species [17].

In contrast with previously reported results, we were not able to demonstrate/reproduce a pan-nuclear localization of Rpl22 in S2R+ cells. Our experiments only revealed a nucleolar localization of the protein, without any detectable association to chromatin. This contrasting result could be explained considering the limitations of the immunolocalization technique, which would not allow for the detection of a small amount of chromatin proteins. Moreover, the differences between the cell lines used in our experimental setup (S2R+) and in previous studies $(\mathrm{Kc})$ should be taken into account. Kc are male derived, while S2R+ derive from females. Kc have a plasmatocyte-like phenotype, while S2R+ combines properties of plasmatocytes and crystal cells [69]. Finally, Kc and S2R+ have different ploidy, since Kc are approximately $4 \mathrm{n}$, while S2R+ are 2.5n [70]. We can, therefore, hypothesize that the nuclear localization and the association to chromatin is cell-type dependent. Consequently, we cannot dismiss the fact that, in S2R+ cells, Rpl22 can also enter the nucleus under particular experimental conditions. An additional limitation of our study is the lack of confocal microscopy analyses, which grants a powerful resolution at the subcellular level. 
Similarly, we did not detect Rpl22 signals on the polytene chromosome arms, nor in the chromocenter. The limitation in terms of resolution using the polytene chromosome to assess the presence of DNA-protein interactions in heterochromatin is due to the under-replicated nature of the chromocenter [71,72]. Moreover, it has been demonstrated that Rpl22 is subjected to post-translational modifications in testis [31]. SUMOylation, phosphorylation, and possibly other unexplored post-translational modifications could also affect the Rpl22 localization and its ability to be engaged in additional functions, other than translation. Post-translationally modified Rpl22 could potentially exit from the nucleolus and associate to chromatin in particular, unexplored, physiological conditions or in response to environmental stresses. This change in localization could be elicited by protein post-translational modification, as demonstrated in previous studies involving Rpl22 [31].

Despite the lack of localization to chromosomes and chromatin, several additional observations support the hypothesis of an involvement of Rpl22 in chromatin dynamics. There are 12 out of 91 Rpl22-interacting proteins that suggest its involvement in chromatinrelated processes. Furthermore, RpL22 has been identified as one of the two hundred genes required for mitotic spindle assembly in Drosophila S2 cells in an RNAi screen [73], and the down-regulation of the RpL22 gene also results in aberrantly short, monopolar spindles in S2 cells. These data together with the demonstration of the DNA binding ability of Rpl22 presented in this paper, offer a new perspective of how Rpl22 could participate in chromatin dynamics, at least under specific conditions that has yet to be determined. Additionally, previous genome-wide ChIP-on-chip analysis in the fission yeast S. pombe revealed the presence of ribosomal protein complexes at transcription sites with unexpected peaks at centromeres, raising the intriguing hypothesis that RP complexes are involved in tRNA biogenesis and possibly centromere functions [57].

\section{Conclusions}

We have presented in vitro evidence of the interaction between a typical heterochromatic sequence and a ribosomal protein in D. melanogaster. However, experiments in vivo do not confirm the results of experiments in vitro, suggesting that further investigation is needed to reveal the physiological role of Rpl22 in the context of the chromosome structure.

While further studies are needed to understand if the Doc5 element has been co-opted to absolve further functions in the heterochromatin, several suggestive hypotheses could be proposed. Doc5 could act as a bidirectional promoter that allows for the transcription of the Bari1 cluster in order to activate the piRNA-mediated repression of the transposition. In this hypothesis, the ribosomal protein Rpl22 could help in the transcriptional activation from this promoter [74] or in the stabilization of non-coding RNAs [54]. Considering that the Bari1 elements tested so far are transpositionally active $[20,21,75]$ and are capable of autonomous transcription [76,77], this hypothesis could at least partially explain the low transposition activity observed in D. melanogaster laboratory strains [20]. In a companion paper, Minervini et al. (Minervini et al. submitted to Genes) also demonstrated that Rpl22 binds in vitro to a transposable element-derived consensus sequence. This observation leads to the hypothesis that ribosomal proteins could be also involved in controlling the activity of TEs in Drosophila, not only at the translation level [78] but also at the transcriptional level. 
Supplementary Materials: The following are available online at https: / www.mdpi.com/article/ 10.3390 /genes12121997/s1, Table S1: List of the yeast clones tested in the $\beta$-Galactosidase assay. Supplementary Figure S1: In vitro assays (EMSA) suggesting the specificity of the Doc5/Rpl22 binding. Supplementary Figure S2: (A). Rpl22 co-localizes with fibrillarin in S2R+ cells. From the left to the right: DAPI, anti-fibrillarin, anti-Rpl22, merged signals. Signal pseudo-coloring in the merged image is as follows. DAPI: blue; Fibrillarin: red; Rpl22: green. The arrowhead in the merged image point to the nucleolus. A magnified detail of the nucleolar co-localization is reported in the inset. (B). Rp122 co-localizes with fibrillarin in polytene nuclei. From the left to the right: DAPI, anti-fibrillarin, anti-Rpl22, merged signals. Signal pseudo-coloring in the merged image is as follows. DAPI: blue; Fibrillarin: green; Rp122: red. Arrowheads in the merged image point to nucleoli. Table S1. List of the yeast clones tested in the Galactosidase assay. Clones carrying Rpl22 sequences are reported in bold.

Author Contributions: Conceptualization, R.M.M.; One Hybrid Experiments, C.F.M., R.M.M.; immunofluorescence experiments, M.F.B.; FISH experiments on polytene chromosomes, R.M. and R.M.M.; in silico analyses, A.P.; supervised the project, L.V. and R.M.M.; writing-original draft preparation, C.F.M., M.F.B., L.V., R.M.M.; writing-review and editing, C.F.M., M.F.B., L.V., R.M.M. All authors have read and agreed to the published version of the manuscript.

Funding: This research received no external funding.

Institutional Review Board Statement: Not applicable.

Informed Consent Statement: Not applicable.

Data Availability Statement: Not applicable.

Acknowledgments: A.P. is supported by a grant from Regione Puglia "Research for Innovation (REFIN)"-POR PUGLIA FESR-FSE 2014/2020. Codice Pratica: B39303C8.

Conflicts of Interest: The authors declare no conflict of interest.

\section{References}

1. Kornberg, R.D. Chromatin Structure: A Repeating Unit of Histones and DNA. Science 1974, 184, 868. [CrossRef] [PubMed]

2. Lindsay, S. Chromatin control of gene expression: The simplest model. Biophys. J. 2007, 92, 1113. [CrossRef]

3. Schmitt, A.D.; Hu, M.; Ren, B. Genome-wide mapping and analysis of chromosome architecture. Nat. Rev. Mol. Cell Biol. 2016, 17, 743-755. [CrossRef] [PubMed]

4. Simpson, R.T. Structure of the chromatosome, a chromatin particle containing 160 base pairs of DNA and all the histones. Biochemistry 1978, 17, 5524-5531. [CrossRef]

5. Consortium, E.P. An integrated encyclopedia of DNA elements in the human genome. Nature 2012, 489, 57-74. [CrossRef]

6. Chen, Z.X.; Sturgill, D.; Qu, J.; Jiang, H.; Park, S.; Boley, N.; Suzuki, A.M.; Fletcher, A.R.; Plachetzki, D.C.; FitzGerald, P.C.; et al. Comparative validation of the D. melanogaster modENCODE transcriptome annotation. Genome Res. 2014, 24, 1209-1223. [CrossRef] [PubMed]

7. Arunkumar, G.; Melters, D.P. Centromeric Transcription: A Conserved Swiss-Army Knife. Genes 2020, 11, 911. [CrossRef]

8. Tachiwana, H.; Yamamoto, T.; Saitoh, N. Gene regulation by non-coding RNAs in the 3D genome architecture. Curr. Opin. Genet. Dev. 2020, 61, 69-74. [CrossRef] [PubMed]

9. Barral, A.; Déjardin, J. Telomeric Chromatin and TERRA. J. Mol. Biol. 2020, 432, 4244-4256. [CrossRef]

10. Zeng, C.; Fukunaga, T.; Hamada, M. Identification and analysis of ribosome-associated lncRNAs using ribosome profiling data. BMC Genom. 2018, 19, 414. [CrossRef]

11. Mélèse, T.; Xue, Z. The nucleolus: An organelle formed by the act of building a ribosome. Curr. Opin. Cell Biol. 1995, 7, 319-324. [CrossRef]

12. Marsano, R.M.; Giordano, E.; Messina, G.; Dimitri, P. A New Portrait of Constitutive Heterochromatin: Lessons from Drosophila melanogaster. Trends Genet. 2019, 35, 615-631. [CrossRef] [PubMed]

13. Larracuente, A.M.; Presgraves, D.C. The selfish Segregation Distorter gene complex of Drosophila melanogaster. Genetics 2012, 192, 33-53. [CrossRef]

14. Berloco, M.; Fanti, L.; Fau-Breiling, A.; Breiling, A.; Fau-Orlando, V.; Orlando, V.; Fau-Pimpinelli, S.; Pimpinelli, S. The maternal effect gene, abnormal oocyte (abo), of Drosophila melanogaster encodes a specific negative regulator of histones. Proc. Natl. Acad. Sci. USA 2001, 98, 12126-12131. [CrossRef]

15. Tritto, P.; Specchia, V.; Fanti, L.; Berloco, M.; D’Alessandro, R.; Pimpinelli, S.; Palumbo, G.; Pia Bozzetti, M. Structure, Regulation and Evolution of the Crystal-Stellate System of Drosophila. Genetica 2003, 117, 247-257. [CrossRef]

16. Caizzi, R.; Caggese, C.; Pimpinelli, S. Bari-1, a new transposon-like family in Drosophila melanogaster with a unique heterochromatic organization. Genetics 1993, 133, 335-345. [CrossRef] 
17. Palazzo, A.; Lovero, D.; D'Addabbo, P.; Caizzi, R.; Marsano, R.M. Identification of Bari Transposons in 23 Sequenced Drosophila Genomes Reveals Novel Structural Variants, MITEs and Horizontal Transfer. PLoS ONE 2016, 11, e0156014. [CrossRef]

18. McGurk, M.P.; Barbash, D.A. Double insertion of transposable elements provides a substrate for the evolution of satellite DNA. Genome Res. 2018, 28, 714-725. [CrossRef] [PubMed]

19. Caggese, C.; Pimpinelli, S.; Barsanti, P.; Caizzi, R. The distribution of the transposable element Bari-1 in the Drosophila melanogaster and Drosophila simulans genomes. Genetica 1995, 96, 269-283. [CrossRef]

20. Palazzo, A.; Marconi, S.; Specchia, V.; Bozzetti, M.P.; Ivics, Z.; Caizzi, R.; Marsano, R.M. Functional Characterization of the Bari1 Transposition System. PLoS ONE 2013, 8, e79385. [CrossRef]

21. Palazzo, A.; Moschetti, R.; Caizzi, R.; Marsano, R.M. The Drosophila mojavensis Bari3 transposon: Distribution and functional characterization. Mob. DNA 2014, 5, 21. [CrossRef]

22. Sandler, L.; Hiraizumi, Y.; Fau-Sandler, I.; Sandler, I. Meiotic Drive in Natural Populations of Drosophila Melanogaster. I. the Cytogenetic Basis of Segregation-Distortion. Genetics 1959, 44, 233. [CrossRef] [PubMed]

23. Pimpinelli, S.; Dimitri, P. Cytogenetic analysis of segregation distortion in Drosophila melanogaster: The cytological organization of the Responder (Rsp) locus. Genetics 1989, 121, 765-772. [CrossRef] [PubMed]

24. Moschetti, R.; Palazzo, A.; Lorusso, P.; Viggiano, L.; Marsano, R.M. “What You Need, Baby, I Got It": Transposable Elements as Suppliers of Cis-Operating Sequences in Drosophila. Biology 2020, 9, 25. [CrossRef] [PubMed]

25. Marsano, R.M.; Milano, R.; Minervini, C.; Moschetti, R.; Caggese, C.; Barsanti, P.; Caizzi, R. Organization and possible origin of the Bari-1 cluster in the heterochromatic h39 region of Drosophila melanogaster. Genetica 2003, 117, 281-289. [CrossRef]

26. Moschetti, R.; Caizzi, R.; Pimpinelli, S. Segregation distortion in Drosophila melanogaster: Genomic organization of Responder sequences. Genetics 1996, 144, 1365-1371. [CrossRef] [PubMed]

27. Marsano, R.M.; Moschetti, R.; Barsanti, P.; Caggese, C.; Caizzi, R. A survey of the DNA sequences surrounding the Bari1 repeats in the pericentromeric h39 region of Drosophila melanogaster. Gene 2003, 307, 167-174. [CrossRef]

28. Zhao, W.; Bidwai, A.P.; Glover, C.V.C. Interaction of casein kinase II with ribosomal protein L22 of Drosophila melanogaster. Biochem. Biophys. Res. Commun. 2002, 298, 60-66. [CrossRef]

29. Bayona-Feliu, A.; Casas-Lamesa, A.; Reina, O.; Bernués, J.; Azorín, F. Linker histone H1 prevents R-loop accumulation and genome instability in heterochromatin. Nat. Commun. 2017, 8, 283. [CrossRef]

30. Koyama, Y.; Katagiri, S.; Hanai, S.; Uchida, K.; Miwa, M. Poly(ADP-ribose) polymerase interacts with novel Drosophila ribosomal proteins, L22 and L23a, with unique histone-like amino-terminal extensions. Gene 1999, 226, 339-345. [CrossRef]

31. Kearse, M.G.; Ireland, J.A.; Prem, S.M.; Chen, A.S.; Ware, V.C. RpL22e, but not RpL22e-like-PA, is SUMOylated and localizes to the nucleoplasm of Drosophila meiotic spermatocytes. Nucleus 2013, 4, 241-258. [CrossRef] [PubMed]

32. Mageeney, C.M.; Ware, V.C. Specialized eRpL22 paralogue-specific ribosomes regulate specific mRNA translation in spermatogenesis in Drosophila melanogaster. Mol. Biol. Cell 2019, 30, 2240-2253. [CrossRef]

33. Gietz, R.D. Yeast transformation by the LiAc/SS carrier DNA/PEG method. Methods Mol. Biol. 2014, 1205, 1-12.

34. Colloms, S.D.; van Luenen, H.G.; Plasterk, R.H. DNA binding activities of the Caenorhabditis elegans Tc3 transposase. Nucleic Acids Res. 1994, 22, 5548-5554. [CrossRef]

35. Marsano, R.M.; Moschetti, R.; Caggese, C.; Lanave, C.; Barsanti, P.; Caizzi, R. The complete Tirant transposable element in Drosophila melanogaster shows a structural relationship with retrovirus-like retrotransposons. Gene 2000, 247, 87-95. [CrossRef]

36. James, T.C.; Eissenberg, J.C.; Craig, C.; Dietrich, V.; Hobson, A.; Elgin, S.C. Distribution patterns of HP1, a heterochromatinassociated nonhistone chromosomal protein of Drosophila. Eur. J. Cell Biol. 1989, 50, 170-180.

37. Marck, C. 'DNA Strider': A 'C' program for the fast analysis of DNA and protein sequences on the Apple Macintosh family of computers. Nucleic Acids Res. 1988, 16, 1829-1836. [CrossRef]

38. Kosugi, S.; Hasebe, M.; Fau-Tomita, M.; Tomita, M.; Fau-Yanagawa, H.; Yanagawa, H. Systematic identification of cell cycledependent yeast nucleocytoplasmic shuttling proteins by prediction of composite motifs. Proc. Natl. Acad. Sci. USA 2009, 106, 10171-10176. [CrossRef]

39. Brameier, M.; Krings A Fau-MacCallum, R.M.; MacCallum, R.M. NucPred-Predicting nuclear localization of proteins. Bioinformatics 2007, 23, 1159-1160. [CrossRef] [PubMed]

40. Coelho, P.A.; Nurminsky, D.; Hartl, D.; Sunkel, C.E. Identification of Porto-1, a new repeated sequence that localises close to the centromere of chromosome 2 of Drosophila melanogaster. Chromosoma 1996, 105, 211-222. [CrossRef] [PubMed]

41. Csink, A.K.; Henikoff, S. Something from nothing: The evolution and utility of satellite repeats. Trends Genet. 1998, 14, 200-204. [CrossRef]

42. Zhou, R.; Hotta, I.; Denli, A.M.; Hong, P.; Perrimon, N.; Hannon, G.J. Comparative analysis of argonaute-dependent small RNA pathways in Drosophila. Mol. Cell 2008, 32, 592-599. [CrossRef]

43. Anger, A.M.; Armache, J.-P.; Berninghausen, O.; Habeck, M.; Subklewe, M.; Wilson, D.N.; Beckmann, R. Structures of the human and Drosophila $80 \mathrm{~S}$ ribosome. Nature 2013,497, 80-85. [CrossRef] [PubMed]

44. Yang, Y.; Xu, S.; Xia, L.; Wang, J.; Wen, S.; Jin, P.; Chen, D. The Bantam microRNA Is Associated with Drosophila Fragile X Mental Retardation Protein and Regulates the Fate of Germline Stem Cells. PLoS Genet. 2009, 5, e1000444. [CrossRef]

45. Celniker, S.E.; Dillon, L.A.L.; Gerstein, M.B.; Gunsalus, K.C.; Henikoff, S.; Karpen, G.H.; Kellis, M.; Lai, E.C.; Lieb, J.D.; MacAlpine, D.M.; et al. Unlocking the secrets of the genome. Nature 2009, 459, 927-930. [CrossRef] 
46. Caizzi, R.; Moschetti, R.; Piacentini, L.; Fanti, L.; Marsano, R.M.; Dimitri, P. Comparative Genomic Analyses Provide New Insights into the Evolutionary Dynamics of Heterochromatin in Drosophila. PLoS Genet. 2016, 12, e1006212. [CrossRef]

47. Tzika, E.; Dreker, T.; Imhof, A. Epigenetics and Metabolism in Health and Disease. Front. Genet. 2018, 9, 361. [CrossRef]

48. Signor, S. Transposable elements in individual genotypes of Drosophila simulans. Ecol. Evol. 2020, 10, 3402-3412. [CrossRef]

49. Spana, C.; Harrison, D.A.; Corces, V.G. The Drosophila melanogaster suppressor of Hairy-wing protein binds to specific sequences of the gypsy retrotransposon. Genes Dev. 1988, 2, 1414-1423. [CrossRef] [PubMed]

50. Georgiev, P.G.; Corces, V.G. The su(Hw) protein bound to gypsy sequences in one chromosome can repress enhancer-promoter interactions in the paired gene located in the other homolog. Proc. Natl. Acad. Sci. USA 1995, 92, 5184-5188. [CrossRef]

51. Minervini, C.F.; Marsano, R.M.; Casieri, P.; Fanti, L.; Caizzi, R.; Pimpinelli, S.; Rocchi, M.; Viggiano, L. Heterochromatin protein 1 interacts with 5'UTR of transposable element ZAM in a sequence-specific fashion. Gene 2007, 393, 1-10. [CrossRef] [PubMed]

52. Bhavsar, R.B.; Makley, L.N.; Tsonis, P.A. The other lives of ribosomal proteins. Hum. Genom. 2010, 4, 327. [CrossRef] [PubMed]

53. Brogna, S.; Sato, T.-A.; Rosbash, M. Ribosome Components Are Associated with Sites of Transcription. Mol. Cell 2002, 10, 93-104. [CrossRef]

54. Schroder, P.A.; Moore, M.J. Association of ribosomal proteins with nascent transcripts in S. cerevisiae. RNA 2005, 11, 1521-1529. [CrossRef]

55. Wool, I.G. Extraribosomal functions of ribosomal proteins. Trends Biochem. Sci. 1996, 21, 164-165. [CrossRef]

56. Warner, J.R.; McIntosh, K.B. How Common Are Extraribosomal Functions of Ribosomal Proteins? Mol. Cell 2009, 34, 3-11. [CrossRef]

57. De, S.; Varsally, W.; Falciani, F.; Brogna, S. Ribosomal proteins' association with transcription sites peaks at tRNA genes in Schizosaccharomyces pombe. RNA 2011, 17, 1713-1726. [CrossRef]

58. Dai, M.-S.; Arnold, H.; Sun, X.-X.; Sears, R.; Lu, H. Inhibition of c-Myc activity by ribosomal protein L11. Embo J. 2007, 26, 3332-3345. [CrossRef]

59. Dai, M.-S.; Sun, X.-X.; Lu, H. Ribosomal protein L11 associates with c-Myc at $5 \mathrm{~S}$ rRNA and tRNA genes and regulates their expression. J. Biol. Chem. 2010, 285, 12587-12594. [CrossRef]

60. Wan, F.; Anderson, D.E.; Barnitz, R.A.; Snow, A.; Bidere, N.; Zheng, L.; Hegde, V.; Lam, L.T.; Staudt, L.M.; Levens, D.; et al. Ribosomal Protein S3: A KH Domain Subunit in NF-кB Complexes that Mediates Selective Gene Regulation. Cell 2007, 131, 927-939. [CrossRef] [PubMed]

61. Wan, F.; Weaver, A.; Gao, X.; Bern, M.; Hardwidge, P.R.; Lenardo, M.J. IKK $\beta$ phosphorylation regulates RPS3 nuclear translocation and NF- $\mathrm{kB}$ function during infection with Escherichia coli strain O157:H7. Nat. Immunol. 2011, 12, 335-343. [CrossRef] [PubMed]

62. Ni, J.-Q.; Liu, L.-P.; Hess, D.; Rietdorf, J.; Sun, F.-L. Drosophila ribosomal proteins are associated with linker histone H1 and suppress gene transcription. Genes Dev. 2006, 20, 1959-1973. [CrossRef]

63. Kharchenko, P.V.; Alekseyenko, A.A.; Schwartz, Y.B.; Minoda, A.; Riddle, N.C.; Ernst, J.; Sabo, P.J.; Larschan, E.; Gorchakov, A.A.; $\mathrm{Gu}$, T.; et al. Comprehensive analysis of the chromatin landscape in Drosophila melanogaster. Nature 2011, 471, 480-485. [CrossRef]

64. Bonnet, J.; Lindeboom, R.G.H.; Pokrovsky, D.; Stricker, G.; Çelik, M.H.; Rupp, R.A.W.; Gagneur, J.; Vermeulen, M.; Imhof, A.; Müller, J. Quantification of Proteins and Histone Marks in Drosophila Embryos Reveals Stoichiometric Relationships Impacting Chromatin Regulation. Dev. Cell 2019, 51, 632-644.e6. [CrossRef] [PubMed]

65. Sinzelle, L.; Izsvak, Z.; Ivics, Z. Molecular domestication of transposable elements: From detrimental parasites to useful host genes. Cell Mol. Life Sci. 2009, 66, 1073-1093. [CrossRef]

66. Cosby, R.L.; Chang, N.C.; Feschotte, C. Host-transposon interactions: Conflict, cooperation, and cooption. Genes Dev. 2019, 33, 1098-1116. [CrossRef] [PubMed]

67. Pane, A.; Jiang, P.; Zhao, D.Y.; Singh, M.; Schupbach, T. The Cutoff protein regulates piRNA cluster expression and piRNA production in the Drosophila germline. EMBO J. 2011, 30, 4601-4615. [CrossRef]

68. Zhao, K.; Cheng, S.; Miao, N.; Xu, P.; Lu, X.; Zhang, Y.; Wang, M.; Ouyang, X.; Yuan, X.; Liu, W.; et al. A Pandas complex adapted for piRNA-guided transcriptional silencing and heterochromatin formation. Nat. Cell Biol. 2019, 21, 1261-1272. [CrossRef]

69. Cherbas, L.; Willingham, A.; Zhang, D.; Yang, L.; Zou, Y.; Eads, B.D.; Carlson, J.W.; Landolin, J.M.; Kapranov, P.; Dumais, J.; et al. The transcriptional diversity of 25 Drosophila cell lines. Genome Res. 2011, 21, 301-314. [CrossRef]

70. Lee, H.; McManus, C.J.; Cho, D.-Y.; Eaton, M.; Renda, F.; Somma, M.P.; Cherbas, L.; May, G.; Powell, S.; Zhang, D.; et al. DNA copy number evolution in Drosophila cell lines. Genome Biol. 2014, 15, R70.

71. Hammond Mp Fau-Laird, C.D.; Laird, C.D. Control of DNA replication and spatial distribution of defined DNA sequences in salivary gland cells of Drosophila melanogaster. Chromosoma 1985, 91, 279-286. [CrossRef] [PubMed]

72. Spradling, A.; Orr-Weaver, T. Regulation of DNA replication during Drosophila development. Annu. Rev. Genet. 1987, 21, 373-403. [CrossRef]

73. Goshima, G.; Wollman, R.; Goodwin, S.S.; Zhang, N.; Scholey, J.M.; Vale, R.D.; Stuurman, N. Genes required for mitotic spindle assembly in Drosophila S2 cells. Science 2007, 316, 417-421. [CrossRef] [PubMed]

74. Lindström, M.S. Emerging functions of ribosomal proteins in gene-specific transcription and translation. Biochem. Biophys. Res. Commun. 2009, 379, 167-170. [CrossRef] [PubMed]

75. Marsano, R.M.; Caizzi, R.; Moschetti, R.; Junakovic, N. Evidence for a functional interaction between the Bari1 transposable element and the cytochrome P450 cyp12a4 gene in Drosophila melanogaster. Gene 2005, 357, 122-128. [CrossRef] 
76. Palazzo, A.; Caizzi, R.; Viggiano, L.; Marsano, R.M. Does the Promoter Constitute a Barrier in the Horizontal Transposon Transfer Process? Insight from Bari Transposons. Genome Biol. Evol. 2017, 9, 1637-1645. [PubMed]

77. Palazzo, A.; Lorusso, P.; Miskey, C.; Walisko, O.; Gerbino, A.; Marobbio, C.M.T.; Ivics, Z.; Marsano, R.M. Transcriptionally promiscuous "blurry" promoters in Tc1/mariner transposons allow transcription in distantly related genomes. Mob. DNA 2019, 10, 13. [CrossRef] [PubMed]

78. Suresh, S.; Ahn, H.W.; Joshi, K.; Dakshinamurthy, A.; Kananganat, A.; Garfinkel, D.J.; Farabaugh, P.J. Ribosomal protein and biogenesis factors affect multiple steps during movement of the Saccharomyces cerevisiae Ty1 retrotransposon. Mob. DNA 2015, 6, 22. [CrossRef] 